(c) SAGE Publications Ltd

London

Thousand Oaks, CA

and New Delhi

1470-594X

200808 7(3) 301-326

\title{
Friendship and commercial societies
}

\author{
Neera K. Badhwar
}

University of Oklahoma, USA

\begin{abstract}
Critics of commercial societies complain that the free-market system of property rights and freedom of contract tends to commodify relationships, thus eroding the bonds of personal and civic friendship. I argue that this thesis rests on a misunderstanding of both markets and friendship. As voluntary, reciprocal relationships, market relationships and friendship share important properties. Like all relations and activities that exercise important human capacities and play an important role in a meaningful life, market relations and activities are essentially structured and supported by ethical norms and, in turn, support these norms. The so-called norms of the market, such as instrumentality and fungibility, come in varying degrees and characterize not only market, but also nonmarket, relationships, including friendship. Furthermore, although market relationships are primarily instrumental, the individuals involved are not. The virtues of markets have their counterparts in friendship, as do their vices. For these and other reasons, market societies are not only not inimical to friendship, they create a more secure matrix for civic and personal friendship, as well as for other important values such as art, science, or philosophy, than any other developed form of society.
\end{abstract}

keywords commercial societies, friendship, moral norms, virtues, vices

\section{Commercial societies and their critics}

\section{1.}

Are commercial societies unfriendly to friendship? Many critics of commercial societies, from both the left and the right, have thought so. They claim that the free-market system of property rights, freedom of contract, and other liberty rights (the 'negative' right of individuals to peacefully pursue their own ends) is impersonal and dehumanizing, or even inherently divisive and adversarial. Yet 
(their complaint goes) the psychology and morality of markets and liberty rights pervade far too many relationships in a commercial society, eroding the bonds of personal and civic friendship.

My main aim in this article is to analyze and evaluate this claim. In this section, I will give an overview of the critics' complaints against various features of the free-market system, discuss the empirical data that might be thought to support their complaints, and show why they largely fail to do so. In Section 2, I will get to the heart of the matter: the nature of the market and of friendship. I will address the thesis that the modes of valuation proper to production are radically opposed to the modes of valuation proper to friendship, love, sexuality, and so on, arguing that the thesis rests on a misunderstanding of both markets and friendship. A proper understanding of the two reveals that, as voluntary, reciprocal relationships, market relationships and friendship share important moral and psychological properties, and are not the natural enemies, or even the odd bedfellows, many critics take them to be. In Section 3, I will address the related thesis that market societies (societies based on the free-market system of property rights, freedom of contract, and other liberty rights) tend to commodify relationships and, thereby, weaken the bonds of personal and civic friendship. I will argue that free markets are the most powerful force for decommodifying or, more generally (since commodification is not the only way of objectifying people), deobjectifying people and relationships. Hence, market societies are not only not at odds with friendship, they create a more secure matrix for civic and personal friendship than any other developed form of society. ${ }^{1}$ Indeed, market societies provide such a matrix not only for friendship, but also for many other important values, such as art, science, and philosophy.

Marx set the tone for the criticisms in question when he declared that the relations of production in a market economy turn the worker's labor into a commodity, thus alienating him from himself and his fellow-men, and creating endemic conflicts of interest. This political economy is sustained by the bourgeois ideology of rights, which, Marx declaims, are the rights of the 'circumscribed individual', of 'egoistic man' isolated from the community. ${ }^{2}$ In the ideal society, presumably, people would give to each other out of love, with no need to stand on their rights. To paraphrase the hero of the 1970 movie, Love Story, in such a society love would mean never having to say, 'Sorry, that's mine.'

In a similar vein, Erich Fromm argues that market societies have created a 'marketing orientation' that leads people to see themselves and others as commodities for exchange. ${ }^{3} \mathrm{He}$ is joined by contemporary critics such as Sybil Schwarzenbach, Elizabeth Anderson, and Margaret Radin, who see similar dangers in market societies. Thus, Schwarzenbach complains that market societies wrongly emphasize production or poiesis over action or praxis, to which, allegedly, belongs the creation and nurturance of relationships. ${ }^{4}$ Again, while Anderson acknowledges that market societies have done much to liberate people from the tyrannies of class and status, and that many, many things are "properly 
regarded as pure commodities', she cautions that, unless market freedoms are limited, the tentacles of commodification will spread through civil society to strangle other forms of valuation, including the intrinsic valuation of friendship. ${ }^{5}$ Similarly, Margaret Radin warns that proposals for universal commodification (the freedom to buy and sell whatever people might want to buy and sell) presuppose and will lead to an inferior form of flourishing. ${ }^{6}$ All three call for political measures to limit commodification by (further) limiting property rights and freedom of contract for the sake of protecting or promoting friendship or a higher form of flourishing.

Communitarians also bemoan the alleged loss of the virtues of community, especially political community, in the United States, calling for a 'politics of the common good' to replace the 'politics of rights and competing interests'. ${ }^{7} \mathrm{~A}$ politics of rights, they say, has created 'atomistic' individuals who have no stake in participating in the life of their political community. ${ }^{8}$ These sentiments are anticipated by the 20th-century Southern conservative intellectual, Richard Weaver, who deplores 'the anonymity and the social indifference of [the] urban man' held together only by 'the cash nexus', and who writes feelingly of 'the rooted culture' of the South, in which each person 'working in his sphere went to make up a whole' with 'a common bond of feeling'. 9

From across the political spectrum, the critics of commercial societies present us with a picture of a society in which people meet in the marketplace (shopping malls, internet auctions, restaurants, and banks) to buy and sell, striking the best deals for themselves, and then going their own separate ways. At best, these visitors to the marketplace abide by what Fromm calls the 'fairness ethic', eschewing force and fraud in their transactions, and respecting each other's rights to live their lives as they see fit. ${ }^{10}$ But they meet and part as indifferent strangers, with no sense of a shared destiny or shared responsibilities. Insofar as they have any interest in politics, their interest is largely partisan and factional. On this picture, civic friendship is conspicuous by its absence from the economic and political life of commercial societies or, at least, in permanent danger from the 'marketing orientation' encouraged by such societies.

\section{2.}

How far is this picture true of life in commercial societies in general and America in particular, where the ideology of individual rights and free markets is probably stronger than anywhere else? Judging from some well-known facts of American life and the spate of articles and books on the sorry state of American society, the picture seems depressingly accurate. Libertarian, left-liberal, communitarian, and conservative critics may all point with dismay at the phenomenon of business interests lobbying local, state, and federal governments for special favors in the form of subsidies or protections, or outright appropriation of others' property, even as they cloak their demands in the rhetoric of protecting free markets and the right to economic opportunity. Communitarians and others may give as an 
example of a politics of competing interests the litigiousness of American society, with legions of trial lawyers enriching themselves by nobly defending the 'right' of their helpless and hapless clients to be protected from the evil blandishments of fattening foods. ${ }^{11}$ Some liberals, such as Anderson and Radin (and, no doubt, many conservatives and communitarians), deplore the relatively new phenomenon of contract pregnancy or surrogate motherhood for improperly commodifying female reproductive labor or children. ${ }^{12}$ If contract pregnancy were to be widely accepted, Anderson argues, it 'would change the way people (parents and brokers) value children generally - from being worthy of love by their parents and respect by others, to being sometimes the alienated objects of commercial profit-making'. ${ }^{13}$ Radin also argues that widespread commodification of surrogate motherhood might have a rhetorical 'domino effect' that leads people to think of women's attributes, especially their reproductive capacities, and of children as commodities. ${ }^{14}$ Similarly, commodified sex (prostitution) debases a gift value, ${ }^{15}$ not only for those who buy and sell sex, but also for others, because it both stems from and encourages a debased attitude toward women's sexuality in the personal sphere. ${ }^{16}$ 'The same masculine sexual desire', states Anderson, 'is gratified in personal and commodified sexual relations. ${ }^{17}$

Again, Schwarzenbach presents the 'disintegration of traditional (Bourgeois) familial relations, and staggering rates of systemic homelessness, drug dependency, illiteracy, and so forth' ${ }^{18}$ as evidence of a breakdown of civic and personal friendship. She claims that the emphasis on liberty rights and production is partly responsible for the damage to friendship, and that the damage can be undone only by moving away from liberty rights and production. ${ }^{19}$ More generally, critics can point at the impressive empirical evidence marshaled by Robert Putnam in support of his thesis that social capital has declined since the $1950 \mathrm{~s}^{20}$ For although Putnam attributes the decline to the privatizing effects of TV, the twocareer family, and other factors, rather than to market norms, one could argue that these factors themselves are ultimately due to the prevalence of market norms.

The gloomy critics, then, seem to be right in complaining that civic and personal friendship in America are in the doldrums, while (and because) markets intrude where they have no business to be, and liberty rights flourish. It would be hasty, however, to accept this dismal conclusion about American society on the basis of the evidence adduced above, much less to generalize it to all commercial societies. For this picture of the loveless society is misleadingly incomplete. Moreover, many of the problems it identifies illustrate not the workings of free markets or the ethics of liberty rights, but, rather, of their violation or disregard.

The fairness ethics of rights and markets assumes that individuals are free and responsible beings capable of interacting with each other in the marketplace and elsewhere as equals. ${ }^{21}$ Nothing in this ethics supports the politics of favoritism and corporate welfare engaged in by business lobbies and politicians eager for votes. Indeed, to use the coercive power of the state to take from Paul (the taxpayer) and give to Peter (the private business) what Peter cannot get voluntarily from Paul 
(the customer) is to engage in the mirror opposite of a market transaction. In addition, while the free-market system leaves people free to sue fast-food joints for seducing them with their greasy burgers, its ethics of fairness and individual responsibility do not support their claim to have been innocent victims.

Again, even if it is true that the practices and attitudes of the surrogacy industry are inconsistent with the surrogate's autonomy and with the respect and consideration due to her, ${ }^{22}$ it does not follow that the practices and attitudes of the parties to the contract are always inconsistent with the surrogate's autonomy and the respect or consideration due to her. Many women who become surrogates do so autonomously, and many couples for whom they are carrying the child develop emotional ties to the surrogates and treat them with respect and consideration. Nor is the baby a mere commodity for the mother or anyone else. Anderson and Radin, however, object even to partial commodification of the baby. ${ }^{23}$ But why should partial commodification be objectionable if the child is treated well both during pregnancy and after birth? Marriage also, after all, is partially commodified, not to mention the professions, art, and almost anything with a legal status. Perhaps Anderson's fundamental objection is that the surrogate gives up the child for her own sake, not the child's, and that this is inconsistent with parental love. ${ }^{24}$ But it is hard to see how the surrogate can be said to be acting only for her own sake, not the child's, given that she is giving up the child to the loving care of its parents.

Let us, however, grant Anderson and Radin their claim that surrogacy involves a debasement in attitudes toward motherhood, pregnancy, and children. Is this a good reason to believe, as they also claim, that if surrogacy is not banned and becomes widespread, it will have a domino effect and lead to such a debasement even among those not involved in surrogacy arrangements? Not really. Such a sweeping statement about the effects of a certain practice and policy on others needs a strong empirical basis in psychology and sociology, a basis that neither author supplies. The same applies to Anderson's claim about prostitution leading to a general debasement of sexuality, and to Schwarzenbach's claim about the emphasis on liberty rights and economic production leading to the breakdown of friendship. As we shall see, Anderson and Schwarzenbach also argue that the modes of valuation proper to pure economic goods or production are radically opposed to the modes of valuation proper to friendship, love, sexuality, and so on. But even if they are right about this radical opposition in the modes of valuation proper to each sphere (and I will argue in Section 2 that they are not), it does not follow that if we do not limit market freedoms, market valuations will spread through all spheres of life and strangle other forms of valuation (if we legalize pot, will we cease to value anything but pot?). Whether this will happen is an empirical question, and in Section 3 I give reasons to think that the tendency of market societies has always been to encourage other forms of valuation, not to strangle them.

Finally, while Putnam's work undoubtedly points to features of American 
society that almost anyone would regard as problematic, his overall picture of American society has been criticized by many as being misleading. ${ }^{25}$ Moreover, Putnam's central thesis, that there has been a decline in social capital since the 1950s, is vitiated by the fact that, as Steven Durlauf points out, his conception of social capital is multiply ambiguous. ${ }^{26}$ Sometimes Putnam uses 'social capital' to mean 'connections among individuals - social networks and the norms of reciprocity and trustworthiness that arise from them ${ }^{27}$ sometimes to mean a sense of 'fraternity', ${ }^{28}$ and sometimes to mean networks understood simply as channels for the flow of information. ${ }^{29}$ Thus, Putnam counts political activities such as voting and working for political parties, or membership in labor unions, as social capital. But voting and membership in labor unions need not create a sense of fraternity, and the sense of fraternity among those who work for the same political party is counterbalanced by the adversarial feelings toward people working for opposition political parties.

In sum, although in some ways American society (like other societies) is a society of mutually indifferent or even antagonistic individuals, the negative picture often painted of it is a highly selective and, thereby, distorted one. For a balanced view, we also need to look at the positive picture.

\section{3.}

No one who has recently ventured from his study into the terrestrial or cyberagora or other public spaces of America, or cast an eye on the patterns of personal relationships, can fail to be struck by the variety of flourishing communities: book clubs, neighborhood associations, support groups for victims of crime or disease, 'nonprofits' that seek to protect various freedoms from the coercive actions of the state here and abroad, and organizations that make it their mission to teach self-sufficiency and relieve hunger in remote regions of the world. There are also astoundingly high levels of private charity, levels that have risen steadily from US\$7.70 billion in 1955 to an incredible US\$260.28 billion in 2005, with 76.5 percent of it coming from individuals. ${ }^{30}$ An unbiased observer also cannot fail to see signs of a national sense of belonging to a single political-cultural community: the hundreds of think tanks dedicated to analyzing and solving the problems of 'our' society, the innumerable print, radio, and TV magazines doing the same, and the many organizations teaching the fundamental constitutional principles of this country. Even the multimillion-dollar support by charitable foundations for Putnam's research into the breakdown of community was, at least in part, an expression of concern for the American community. These observations are borne out by extensive research that leads Robert Wuthnow to conclude that although communities have become looser and more fluid, they are no less extensive than before. ${ }^{31}$ In short, Alexis de Tocqueville's observation in Democracy in America that Americans are a society of joiners still holds true. ${ }^{32}$ Many of the communities of yesteryear have disappeared, but they have been replaced by a variety of new ones. 


\section{4.}

Nevertheless, these criticisms of commercial societies cannot be met simply by correcting the one-sided picture critics sometimes give of American society or pointing out their mistaken causal analyses of the ills of American society. For it may still be the case that there is something about the psychology of market relations that is antagonistic to the bonds of community, family, and friendship. This might explain why the lament over the breakdown of these bonds has been sounded repeatedly since the very dawn of commercial society in 18th-century England and Scotland. No less a figure than Adam Ferguson, who at first criticizes pre-commercial society for its pervasive competitiveness in all relationships, later warns against the passing of tight-knit communities and the coming of a society in which community members may 'have no common affairs to transact but those of trade'. ${ }^{33}$ Similar warnings are repeated by Marx and Ferdinand Tönnies ${ }^{34}$ a century later, by Weaver in the mid-20th century, by Fromm in the 1940s and 1950s, and by Anderson, Schwarzenbach, and Radin in contemporary times. Some of these critics apotheosize pre-commercial societies or herald the brave new world of the post-capitalist future, others simply want to make market societies safe for 'the higher things' in life. But all agree that the orientation or mode of valuation proper to market transactions is hostile to the mode of valuation proper to personal and civic friendship, so that wherever you have the first, you have a weakening, or even demise, of the second. An adequate response to these critics requires analyzing this thesis of the psychology of market relations. Anderson offers the most developed argument for this thesis, so I will start with a description of her argument.

\section{Market norms and the norms of friendship}

\section{1.}

The modes of valuation proper to market production and market relations, Anderson argues, are radically opposed to the modes of valuation proper to friendship, love, sexuality, and so on. We value pure commodities and market relations only insofar as they are useful as means to our independently defined ends, whereas we value the latter as ends in themselves. ${ }^{35}$ But use 'is a lower, impersonal, and exclusive mode of valuation' that sees things as fungible and capable of being 'traded with equanimity for any other commodity at some price'. ${ }^{36}$ This stands in contrast to respect, appreciation, or love, which are modes of valuation for entities and relationships that are seen as having intrinsic, irreplaceable value. Similarly, Schwarzenbach argues that instrumental productive activity (poiesis) is a lower form of activity than the noninstrumental activity (praxis) of love and care (epimeleia). It is, again, because of the instrumentality and fungibility ('market-alienability') of commodities that Radin fears that permitting universal commodification, with its market rhetoric and market methodology, would lead us to think even of personal relationships and attributes 
of personhood as commodities. All three writers conclude that we should limit economic liberties through prohibition or regulation of certain markets as a way of expressing the intrinsic value we place on persons and personal or civic relationships and preventing market norms from spreading. ${ }^{37}$

Since goods and relations can be commodified to different degrees, it is useful to start with what Anderson calls pure economic goods and relations. A pure economic good, says Anderson, is a good whose 'production, distribution, and enjoyment are properly governed' by market norms and whose value 'can be fully realized through use'. ${ }^{38}$ A pure economic good is a pure commodity, properly valued as a mere means to 'independently defined ends'. ${ }^{39}$ The market norms that 'exclusively' govern its production, distribution, and enjoyment have 'five features that express the attitudes surrounding use and embody the economic ideal of freedom: they are impersonal, egoistic, exclusive, want-regarding, and oriented to "exit" rather than "voice". ${ }^{40}$ Schwarzenbach echoes some of the same claims. The 'proper concern' of production, she says, is 'with its product (and only indirectly with human relations or needs); [and] its incentive is usually exclusive, private ownership or benefit to the self' ${ }^{41}$ Thus, economic rights such as the right to private property and the right to contract promote 'selfish' behavior, in contrast to welfare rights, which promote the nurturing, 'reproductive' activities of civic friendship. ${ }^{42}$

These claims about the nature of commodities and market relations may be illustrated by the following imaginary, everyday market transaction. When I give US $\$ 2$ to the street vendor in exchange for a hot dog, I am justified in seeing and valuing the transaction and my US\$2 simply as a means to my gustatory satisfaction. My relationship to the vendor is impersonal, in that we have no knowledge of, or concern for, each other's social status or character. The relationship also seems to be purely egoistic, insofar as both the street vendor and I seem to be concerned only with our own independently defined interests, with no regard for each other's interests (except as means to our own interests). For all these reasons, the goods exchanged (the money and the hot dog) as well as my relationship to the vendor are entirely fungible: any vendor on the street who made a good hot dog would have done equally well, as would any hot dog from his cart in exchange for any two dollar bills from my wallet. Our relationship is also exclusive, want-regarding, and oriented to exit rather than voice. The vendor and I have exclusive rights to the goods exchanged, which are distinct and not shared, we both respond to each other's wants without asking if these wants are worthy (he does not quiz me about the nutritional value of my daily diet and I do not quiz him about the worth of his occupation), and we both know that, as market actors, we can influence each other's behavior chiefly through trade or a refusal to trade - a simple 'take it or leave it' (exit).

It should be easy to see the differences between my relationship to the vendor and a close friendship. Both involve an exchange of goods, but in friendship these goods, as Anderson puts it, are 'jointly realized', and are 'not merely used but 
cherished and appreciated, for they are expressions of shared understandings, affections, and commitments' ${ }^{43}$ Further, they can be exchanged only as gifts, and they aim 'to realize a shared good in the relationship itself, whereas market exchange aims to realize distinct goods for each party' (ibid., p. 151). Presumably, Anderson does not mean that no good in a friendship is distinct or separately realized, but that the goods central to friendship, such as trust, affection, sympathy, and companionship, are shared and jointly realized. What makes something a shared good is not only that it is enjoyed with others, but that it is enjoyed 'according to shared understandings of what it means' ${ }^{44}$ Moreover, even though both gift and market exchanges require reciprocity, the form and timing differ. In friendship we expect reciprocity 'only in the long term', for 'gifts are given for the friend's sake, not merely for the sake of obtaining some good for oneself in return'. ${ }^{45}$ Schwarzenbach also stresses that the 'proper goal' of reproductive praxis 'in the best case' is not 'exclusive private ownership but a shared appropriation of the human world' and 'unselfish satisfaction'. ${ }^{46}$

The psychology of friendships, then, seems radically different from the psychology of market relationships. Hence, one can understand the alarm of those who think that if market rhetoric and market norms were to spread into all areas of life, they would replace (as both Marx and Thomas Carlyle complained) the 'human nexus' with the 'cash nexus'. Before we join in the alarm, however, we need to ask the following questions.

\section{2.}

Is the kind of relationship with the hot dog vendor I used above to illustrate market norms paradigmatic of market relations, or are there many kinds of market relations? Even if the vendor relationship is paradigmatic of market relations, is it a purely commodified relationship (that is, governed only by the market norms just described) or is it also essentially governed by certain norms it shares with non-commodified relationships, including certain forms of friendship? To be sure, if a market relationship concerning the production or exchange of a pure commodity is defined as a purely commodified relationship, then the answer must be that the vendor relationship is purely commodified and that it shares no norms with friendship. But this answer, as I argue below, cannot be right; for although there are pure commodities and purely commodified relationships (such as the slave master's to the slave or the hostage-taker's to the hostage), there can be no purely commodified market relationships. ${ }^{47}$ Again, even if economic activities concerning the production or exchange of pure commodities can be properly valued entirely instrumentally, can they not also be properly valued as ends? Finally, even if the value of some economic activities is entirely instrumental, are they necessarily inferior to 'friendship activities', or is this an unwarranted conclusion? If these criticisms of commercial activities and relations are mistaken, then the claim that the norms governing them are at odds with the norms governing intrinsic goods such as parental love, sexuality, or, 
more generally, love and friendship, is ill-conceived, as is the proposal to limit (further) property rights and freedom of contract for the sake of preventing a general devaluation of intrinsic values.

I will argue that market relations come in many stripes, but none is entirely commodified because none is entirely instrumental. Moreover, like all relations and activities that exercise important human capacities and play an important role in a meaningful life, market relations and activities are essentially structured and supported by ethical norms and, in turn, support these norms. If the ethically bleak picture of market relations given by its critics seems right at first sight, it is because it largely fits many simple, everyday transactions such as buying hot dogs from unknown street vendors. But the minimalistic picture does not completely describe even such transactions (Section 3 below), which, in any case, are not paradigmatic of market relations. Furthermore, as the following examples show, to the extent that this picture is true of the vendor relationship, it is also true of many nonmarket relationships. So the sharp dichotomy between market and nonmarket relationships is called into question from both sides: market relationships are not entirely instrumental, and nonmarket relationships are often largely instrumental.

\section{3.}

Consider the relationship of two previously unacquainted club members playing a game of squash. The value of the relationship to them is primarily instrumental. They are playing each other only for the sake of a good, invigorating game, and any other club member who played equally well would have served their purposes just as well, regardless of his character or social status. Consider, again, the relationship of an audience to unknown actors in a play. The play itself may have aesthetic, psychological, and moral value, but the actors' value to the audience is primarily instrumental, lying in how well they play their parts. The audience is there exclusively for its own enjoyment or enlightenment, and any other cast of actors that could play the parts as well would have been just as welcome, regardless of their individual identities. Hence, these nonmarket relationships are no different from my market relationship to the unknown hot dog vendor: both are equally instrumental, impersonal, egoistic, fungible, want-regarding, and oriented to exit rather than voice.

It might be thought that since the alleged nonmarket relationships are themselves based on market transactions (a fee for club membership and a ticket for the play), my comparison does not really make my point. The underlying market transactions, however, do not affect my argument, because the instrumentality, impersonality, fungibility, and so on would obtain, for the reasons given above, even if the club membership or play were free. This suggests that the crucial factor in making the vendor-buyer relationship largely instrumental and so on is not that it is a market relationship, but that it is a transient exchange relationship between strangers. Hence, other things being equal, we should expect instru- 
mentality, impersonality, and so on to vary with the length and depth of an exchange relationship. To see this, let us imagine that the two squash players, having enjoyed the first unplanned game, decide to play together regularly. Even if their interaction is limited to squash interspersed with occasional pleasantries, even if their knowledge of each other's character and personality is strictly limited to their comportment on the squash court, if they like each other and miss seeing each other when one of them cannot make it, their relationship has turned into a friendship - of the sort that Aristotle calls a 'pleasure friendship' ${ }^{48}$ And so, even though the relationship is still primarily an instrumental, exchange relationship, in the sense that it would not endure if one of them lost interest in squash or became unable to play, it is less instrumental and fungible than before, because another equally good player would not do just as well.

The same process occurs in market relationships, such as between street vendors or workers in grocery stores and their regular clients. As the interactions extend over time and the faces become familiar, a mutual and active liking, pleasure, and goodwill replace the abstract goodwill that most of us bear toward strangers. The market relationships have now become, to borrow Aristotle's term, 'utility friendships' - friendships based on utility. ${ }^{49}$ Indeed, sometimes the friendship aspect of the relationship can even be dominant, as when the market exchange simply serves as an occasion for a friendly visit. ${ }^{50}$ If another street vendor or store-owner were to take the place of this one, there would be a sense of loss, even if, in time, the sense of loss disappeared.

More sustained market relations give rise to more sustained utility friendships that the Romans called necessitudo - friendships based on the necessity of the situation. As Adam Smith puts it:

Among well-disposed people, the necessity or conveniency of mutual accommodation, very frequently produces a friendship not unlike that which takes place among those who are born to live in the same family. Colleagues in office, partners in trade, call one another brothers; and frequently feel towards one another as if they really were so. ${ }^{51}$

Business partners often develop a friendship on the basis of their shared interests and cooperation at work, as do representatives of businesses that rely on each other's products and work closely together. Their mutual liking, goodwill, and pleasure in each other's company create loyalties that may even sometimes get in the way of their business interests. ${ }^{52}$ Hence, even though (by hypothesis) their friendship would not last if their interests changed, their sense of loss would be greater than that of the utility friends described above. This makes their friendship even less instrumental, fungible, and so on.

But it is not only qua friendships that these long-term business relationships differ from transient exchange relationships in their degree of instrumentality, fungibility, and so on. They differ even qua business relationships. All cooperative market relationships are based on shared interests, but business partners and interdependent businesses also shape each other's interests to a significant extent. 
Their market exchanges aim to realize not only distinct, exclusive goods for each party, but also the shared good of the joint or interdependent business enterprise. In such businesses, the parties involved also care about each other's character, since their business dealings require mutual trust and trustworthiness. Indeed, some businesses go to great lengths to get to know their clients' trustworthiness. For example, Lloyd's of London required their big business clients to visit them for several days each year, even if this required sailing across the Atlantic. In addition, trust based on personal knowledge and a complex private system of social and business sanctions plays a crucial role in the diamond trade among Jewish merchants in New York, who close deals worth millions of dollars with nothing more than a verbal promise or a handshake. ${ }^{53}$ Contrary to Anderson, then, even though these business relationships concern trade in pure commodities, they are neither impersonal nor egoistic, and the parties do not regard each other or their relationships as easily replaceable.

These examples show three things we need to do to understand the nature of market relations. First, we need to consider different kinds of market relations, not only transient vendor-seller-type relations. Second, we need to consider them in the context of nonmarket relations of various kinds, such as the audience-actor relation, and not only in the context of friendships. Third, we need to consider them in the context of different kinds of friendships, not only in the context of intimate, committed friendships based on the friends' characters and personalities. When we modulate our inquiry in this fashion, we can see that the features of instrumentality, fungibility, impersonality, and so on are neither peculiar to market relations, nor an all-or-nothing affair; rather, they are present in varying degrees in both market and nonmarket relationships, including friendship. We can also see that the psychology of market relations not only does not necessarily militate against friendship, it often gives rise to friendship, because awareness of mutual advantage naturally creates amicable feelings.

This returns me to a point I have discussed only briefly. I pointed out above that, like a committed friendship, a long-term business relationship is also a shared good, made up of mutual trust, understanding, and commitment from the parties to the relationship. But in fact, to some extent all exchange relations of mutual advantage, even transient ones, are shared goods, even though the goods they exchange are exclusive and distinct. Sellers and buyers in a market shape each other's interests, and share an interest in the continuation of a relationship of mutual advantage. ${ }^{54}$ Indeed, as a network of nonexclusive, mutually advantageous relations held together by a mutual awareness of these advantages and a shared understanding of its principles, the market itself is a shared good.

We may conclude, then, that any view that makes a sharp dichotomy between market norms and the norms of friendship rests on too blunt an understanding of both markets and friendships. This is not to say that there are no important differences between them. The most important difference is that, whatever the personal value of a business relationship (the enjoyment, the mutual learning, or the 
psychological support) insofar as it is a business relationship, it is primarily a means to the success of the business. Hence, for example, partners who continued their partnership even after it became harmful to their business, or companies that continued trading even if they gained nothing from the trade, would, in economic terms, be simply irrational (even if their actions were rational all things considered by virtue of other overriding reasons). Good business relationships qua business relationships must be primarily instrumental. By contrast, the best friendships must be primarily ends in themselves. Schwarzenbach takes this to imply that friendships belong to a higher moral plane than business relationships or, indeed, than any commercial activity.

\section{4.}

Schwarzenbach appeals to Aristotle to distinguish between praxis as action that has its end within itself and necessarily conveys character and poiesis as action that has its end outside itself and does not convey character. ${ }^{55}$ Friendship activities are forms of praxis motivated by 'shared' concerns and 'unselfish satisfaction', whereas economic activities are forms of poiesis motivated 'usually' by exclusive, private, selfish concerns. ${ }^{56}$ She concludes from these premises that economic productive activities are morally inferior to the 'reproductive' activities of friendship.

I have already argued that many of the alleged differences between productive activity and friendship are either nonexistent or highly exaggerated. But even if we grant all of Schwarzenbach's premises, her conclusion does not follow, as shown by the following analogy. Many scientific activities are exclusive and primarily means to the end of some human need or desire, and all scientific and artistic activities are concerned only indirectly with human relationships. But it is clearly false to think that scientific and artistic activities are inferior to relationship activities. Moreover, unless we can defend the dubious Aristotelian assumption that only the good can love each other as ends, the mere fact that a relationship is an end in itself does not guarantee its moral worth, for it might be based on a shared commitment to some evil vision. ${ }^{57}$ Hence, we must also reject the undefended (though distressingly widespread) assumption made by Schwarzenbach and other authors, namely, that shared activities are inherently better than unshared activities: the former may be evil and the latter deeply worthwhile.

Schwarzenbach seems to think that all rational (chosen) activities that 'go toward reproducing a particular set of relationships between persons over time', such as cooking for one's family, playing with one's children, and the other activities that 'women have traditionally performed in the home', are instances of 'reproductive praxis' ${ }^{58}$ But this definition of reproductive praxis turns even productive activities into praxis. For surely a woman might cook only for the sake of feeding her children and not at all for its own sake, or take a job only for the sake of supporting her children and herself and not at all because she likes it. 
Recognizing this, Schwarzenbach then states that many of these activities 'can be performed as ends in themselves' ${ }^{59}$ But this implicitly acknowledges that some rational (chosen) activities that 'go toward reproducing a particular set of relationships between persons over time' need not be performed as ends.

In any case, some things are much better done as means, even mere means, than as ends. A mother who potty-trained her children as an end in itself would be doing her children no favor, and one who punished them as an end would be sadistic. The insistence that doing something as an end is always better than doing it as a means amounts to 'end-fetishism'. Indeed, contra Schwarzenbach's (and Anderson's) claims, even when something is properly regarded as an end, it is not always morally higher or more important than the means to it. Consider my relationship to the hot dog vendor. I enter into the relationship only as a means to the end of my gustatory satisfaction. But in certain respects the relationship (how I treat and am treated by the vendor) is more important than my enjoyment of the hot dog. The reason is obvious: people are more important ends than anyone's gustatory satisfaction. The deeper point, generalizable to all morally legitimate human relationships, is that even relationships that come into being for purely instrumental reasons have a noninstrumental dimension, because people are not mere instruments to each other's ends, but ends in themselves. A relationship that fails to recognize this is a relationship of predator and victim, or mutual predators and victims, not a relationship of voluntary trade.

None of this is to deny that when the means to an end is not a human being or a human relationship, and the end in question is morally permissible, the end is unqualifiedly more important than the means, since the value of the means derives from the value of the end. Hence, if economic production were only a means to the ends of survival, comfort, pleasure, personal relationships, and so on, then it could fairly be said to be lower on the scale of value than these ends. But there is no reason to think that production is only a means to these ends (although its role as a means is hardly negligible in the absence of a regular delivery of manna from heaven). To relegate it to a lower realm of human existence, as Schwarzenbach and other critics do, is to show a serious misunderstanding of its role in a good human life. People engage in economic production for many of the same sorts of reasons that they engage in intellectual or artistic production (proving theorems, writing treatises, and making music) or, indeed, building friendships: for the sake of exercising their creative or productive powers in worthwhile enterprises. Although Fromm fails to appreciate this about economic production, he appreciates better than even some defenders of free markets the meaning and importance of productiveness as such. 'Productiveness', he states, 'is man's ability to use his powers and to realize the potentialities inherent in him', ${ }^{60}$ and again, "Productiveness means that he experiences himself as the embodiment of his powers and as the "actor"; that he feels himself one with his powers and at the same time that they are not masked and alienated from him. ${ }^{61}$

When productiveness is understood as a positive expression of human poten- 
tiality and not simply as a means to the ends of survival, comfort, or wealth, we can appreciate the entrepreneurial and creative spirit that animates all worthwhile activities, including market activities. And then we can understand why, for instance, a philosophy $\mathrm{PhD}$ would find satisfaction in the enterprise of producing skateboards 'adorned with uplifting art' ${ }^{62}$ Worthwhile activity in any sphere exercises our imaginative, emotional, and intellectual powers to create things of worth and, thereby, engages and reshapes our identity. This is at least one reason why the failure of a business enterprise can be as devastating as the failure of a long-term scientific enterprise - or of a long-term friendship. Seeing commercial activities as 'poiesis' and friendship as 'praxis' distorts the nature of both business enterprises and friendships.

The fact that economic activities and relationships play an important role in a meaningful life implies that the market can no more be adequately described in morally neutral terms than can friendship: moral norms inform all worthwhile human activities. Economic activity, as Ludwig von Mises argues, must be understood in the context of a general theory of human action. ${ }^{63}$ In the next section, I will argue that the fairness ethics that structures the market has been and is a powerful force for promoting end values, and that the so-called faults of the free market are simply the faults of free human beings in every sphere of action.

\section{The ethics of the market}

\section{1.}

As we have seen, Fromm acknowledges that the market could not exist without the ethics of fairness, with its prohibition of force and fraud and the principle of equal exchange in goods and feelings. But he thinks that fairness ethics has nothing to say to those with nothing to trade, for it neither endorses nor prohibits love of neighbor or charity. The ethics needed by friendship and community, he holds, is the ethics of Judaism and Christianity, which requires that you 'love your neighbor, that is . . f feel responsible for and one with him' ${ }^{64}$

The fact that fairness ethics is not a complete ethics is, however, neither here nor there. The ethics of universal love is not a complete ethics either, and attempts to make it so by reducing all ethical concepts to love are either implausible or not genuine reductions, since they simply reproduce the putatively rejected distinctions within the general category of love. Furthermore, fairness ethics is far from negligible, as Fromm's dismissive tone suggests. On the contrary, it is of the first importance in all voluntary, reciprocal relationships, including personal and civic friendship. For all such relationships involve the exchange of something deemed by the parties to be worth exchanging, whether this be a material good, a valuable idea, an entertaining conversation, or a lovable self. A fair exchange of goods or feelings requires a sense of fairness, honesty, trustworthiness, and the ability for trust. Even in a transient relationship, such as the vendor-buyer or squash-partner relationship, although neither party cares about the other's overall character, both 
parties care about each other's reliability as traders or partners and behavior. Moreover, such ongoing fair exchanges not only presuppose trust and trustworthiness, they generate further trust and trustworthiness, thereby providing the necessary matrix for the flourishing of civic friendship.

\section{2 .}

This is not to say that all is well in the marketplace. Much that is deemed worth trading in the market may express morally repugnant values or be detrimental to the well-being of consumers on any plausible conception of human well-being. The proliferation of multicolored snake oils masquerading as nutritional supplements or instant cures is only one obvious example. But snake oils are hardly inventions of the free-market system, and are at least usually less dangerous and more pleasant than the exorcisms or potions of our ancestors. The surrogacy industry's frequent lack of respect and consideration for the surrogate mother and her reproductive labor is another example of a morally repugnant attitude (see Section 1.2). Even this, however, is not a product of the free-market system. In many pre-commercial societies, not only the value of women's reproductive labor, but their very value as human beings has been, and continues to be, measured by their ability to produce healthy sons, with rejection or ill-treatment by the husband and his family as the frequent price for failing in this function. My general point here is that morally repugnant values or actions are not limited to commercial societies or the realm of commerce: they exist in the press, the podium, the pulpit, and politics, as well as friendships and communities. As the feminist writer, Adrienne Rich, observes, 'We assume that politicians are without honor. We read their statements trying to crack the code.' ${ }^{65}$ For although 'Men have been expected to tell the truth about facts, not about feelings . . . even about facts they have continually lied.'

We are familiar with the way businesses sometimes exploit customers' or competitors' trust or short-sightedness with misleadingly worded contracts or ads or with bait and switch techniques. We are also familiar with fly-by-night schemes and counterfeit coin. But each of these has its counterpart not only, say, in politics and religion, but also in friendship. A friendship can be fraught with misleading subtexts or outright deceptions. Rich describes a woman who lies in her personal relationships: 'A subject is raised which the liar wishes buried. She has to go downstairs, her parking meter will have run out. Or, there is a telephone call she ought to have made an hour ago.' ${ }^{66}$ Again, 'She is asked, point-blank, a question which may lead into painful talk: "How do you feel about what is happening between us?" Instead of trying to describe her feelings in their ambiguity and confusion, she asks, "How do you feel?" . . . Then the liar learns more than she tells' (p. 475) and gains power over her friend. Again, like a counterfeiter or fly-by-night businessman, one person may pretend to befriend another for who he is when what he really desires is some monetary or professional advantage. Such a person, says Aristotle, is worse than 'debasers of the currency', 
because in debasing the currency of friendship, he 'debases something more precious' 67

It might be thought that even though human beings wrong each other in all realms of life, there is still a difference between friendship and commerce, namely, that manipulation or exploitation of customers' ignorance, fear, or shortsightedness that stops short of outright fraud is regarded as fair play in commerce, but not in friendship. ${ }^{68}$

In order to consider this objection properly, one must first distinguish between, say, misleading ads, on the one hand, and ads that make no attempt to hide the fact that they are 'dressing up' their products to make them more attractive rather than to mislead the customer (for example, despite the picture advertising the latest perfume, no one can possibly take it to claim that a woman who wears it will be mobbed by men). Such attempts are no more dishonest or exploitative than getting dressed up for a date (for example, no one can seriously believe that women have naturally bright-red lips or pink fingernails). Again, it is hard to see the deception in the Shane Company's former advert, 'Now you have a friend in the diamond business.' For on the one hand, no one can seriously take that to mean that he has a buddy at the company he can just call up for a casual chat (although one person apparently did), ${ }^{69}$ and, on the other, anyone would be right to believe that he will find someone friendly at the Shane Company eager to make a mutually profitable deal rather than to gyp him. By contrast, ads that, with the clever use of emphasis and omission, make it sound (falsely) as though the advertised product is both one-of-a-kind and indispensable to your well-being, without uttering a single literal falsehood, are examples of objectionable forms of exploitation and manipulation that stop short of outright fraud. To quote Rich again, 'Lying is done with words, but also with silence. ${ }^{70}$

But is it true that such subtle deceptions and manipulations are regarded as fair play in commerce, but not in friendship, as the critic alleges? No doubt some people hold that all bluffing that is not outright fraud is 'fair' in commerce as it is in poker, but not everyone does. ${ }^{71}$ Moreover, attitudes toward deception and manipulation in personal relationships also vary. Most people hold that subtle deceptions and manipulations in intimate non-erotic friendships are wrong, but not everyone does. In addition, many people believe that some kinds of deceptions or manipulations are perfectly fair in romantic or marital friendships. Indeed, it is in love (and war), not in commerce, that the common adage claims that all is fair. Again, many people hold that to protect a close friend's interests, it is justifiable to deceive or manipulate a lesser friend, an innocent stranger, or a business. Indeed, some people go further and justify even outright lying or cheating in these contexts. But if deliberately inflicting a cost on people by misleading, manipulating, or cheating them is wrong, except under very special circumstances (and every non-rigorist in ethics must allow some exceptions), then it is wrong whether they are close friends, lovers, lesser friends, strangers, businesses, or customers, regardless of what some or most people think. ${ }^{72}$ 
In both markets and friendship, however, these manipulations and exploitations are exceptions to the rule; neither markets nor friendship would exist if they were the rule. Misleading advertising inflicts a cost on the business by inviting skepticism; and when misleading advertising is conjoined with the widespread business policy of ensuring customer satisfaction by accepting returns, it inflicts a further cost on the business. Moreover, just as the virtues of honesty, trustworthiness, and reciprocity are partly constitutive of friendship, they are partly constitutive of market relationships. Hence, just as to the extent that someone 'debases the currency of friendship' he is deficient as a friend or, at the extreme, not a friend at all, so to the extent that a practice debases the currency of open and voluntary exchange, it is deficient as a market relationship and, at the extreme, not a market relationship at all.

The faults that exist in a free-market system are the faults not of free markets, as such, but of free human beings in every sphere of action; for the most part, all that changes from one sphere to another is the form in which these faults appear. There might be vices that are peculiar to market relationships, vices to which friendship and other forms of community are immune. But the converse is also true: there are vices that are peculiar to friendship and other relationships based on individual, ethnic, religious, or national identity, vices to which markets are immune. One example is an objectionable form of exclusivity: friends and other communities of identity can create a closed world from within which outsiders are seen as potential enemies or lower life-forms. ${ }^{73}$ Markets, by contrast, are open to everyone with something to trade; indeed, identity considerations are contrary to market success, and hence tend to wither away in the marketplace.

\section{3.}

I pointed out earlier that it is a mistake to think that market norms see individuals as mere means to business ends. I now want to argue more strongly that the opposite is implicit in the idea of the fairness ethics and, indeed, that free markets and liberty rights are ultimately justified by the recognition that people are free, selfresponsible agents, entitled to pursue their own ends, and deserving of respect as ends in themselves. It is at least partly this recognition that prevents me from even thinking of filching a bag of chips from the vendor's cart, and the vendor from calling me names for giving him soiled dollar bills. This exchange of the moral good of mutual respect for each other as ends forms the matrix for the exchange both of commodities and of other goods in reciprocal, voluntary relationships. Just as the goods particular to friendship, such as affection and companionship, 'are not merely used but cherished and appreciated . . . [as] expressions of shared understandings, affections, and commitments',${ }^{74}$ so the moral good of mutual respect common to all types of reciprocal relationships is not merely used, but cherished and appreciated as an expression of shared interests, understandings, and commitments.

Such mutual respect in market exchanges relates us as equals, and stands in 
stark contrast to exchange relations based on hierarchy or status, such as those between lord and servant. The vendor sells his wares for the same price to visiting lords and local plebes alike, and can tell both alike to take them or leave them. There may well be a dignity and self-respect attached to a person's hereditary station in life, as some communitarians and conservatives nostalgic for the feudal past tell us. ${ }^{75}$ But a dignity grounded in an individual's hereditary station is, by definition, not portable, and must be left behind should an individual's overlord oust him from his station. Nor is the dignity of those in a lowly station equal to the dignity of those in an elevated station. By contrast, a dignity grounded in our nature as free and self-responsible agents, all equally free to pursue our own plans and equally free to enter or leave relationships, goes with us wherever we go, and relates us to each other as equals. But a general recognition of and respect for this dignity requires an economic and political system that enables people to realize their nature as free and self-responsible agents. Even if the beggar and the alms-giver both believe that, as a human being, the beggar is worth no less than anyone else, it is hard for either of them genuinely to feel this so long as the beggar acts like a beggar, and it is hard for the beggar to act otherwise so long as he is a beggar.

It is not surprising, then, that it is only with the increased opportunities created by market societies and the rule of law that the idea of the fundamental equality of persons qua persons (an idea praised alike by Mencius, Buddhists, Stoics, and Christians) became firmly established. ${ }^{76}$ It is instructive to note that David Hume and Adam Smith celebrated the rise of commerce not only for bringing prosperity to the many, but also for promoting the rule of law, liberty, and good character. ${ }^{77}$ Unlike the later romantics of feudalism, both Hume and Smith saw dependency as creating servility. ${ }^{78}$ The new commercial society broke down the old feudal hierarchies of power that had kept the many dependent on the few, diffusing power by diffusing freedom and wealth and promoting the rule of law. The increased economic opportunities and security offered by the cities freed people of the need to stay in their clans or with their feudal lords for sustenance or protection. ${ }^{79}$ By enabling them to strike out on their own and make their own lives, commercial society made it possible for them to earn the pride that comes from independence and self-reliance; by breaking the shackles of inherited status, the market order made it possible for people to see themselves as equals and ends in themselves.

\section{4.}

These changes were also propitious for civic and personal friendship. In precommercial societies, friends and enemies were created by custom, station, and estate - and most strangers were potential enemies. ${ }^{80}$ The universalism of the new commercial society created a public space characterized by a hitherto unknown openness and friendliness. No longer potential enemies, strangers had enough goodwill and trust to make contracts and cooperate, as well as to volun- 
tarily help each other. It was through the equality and freedom produced by commercial society, then, that the civic friendship that Aristotle thought required a good legislator became widespread and entrenched. As Hume put it, in 'the more polished ... and luxurious ages' (the ages in which people 'flock into cities' and 'love to receive and communicate knowledge', the ages in which commerce, knowledge, and the 'mechanical' and 'liberal' 'arts' flourish), 'Both sexes meet in an easy and sociable manner; and the tempers of men, as well as their behaviour, refine apace. So that ... it is impossible but they must feel an encrease of humanity, from the very habit of conversing together, and contributing to each other's pleasure and entertainment. ${ }^{81}$

On the personal front, commercial society reduced the prevalence of utilitarian friendships, as well as the sort of pretend friendship found in court society, where every detail of 'etiquette, ceremony, taste, dress, manners, and even conversation ... was an instrument in the prestige-struggle' ${ }^{82}$ Positively speaking, commercial society enabled people from different walks of life to form friendships on what Smith, like Aristotle, regarded as the firmest and highest grounds of all: good character. ${ }^{83}$ The ideal of marriage based on love rather than (ironically, for those fearful of the effects of commodification) on wealth or prestige also became widespread only with the emergence of commercial societies. ${ }^{84}$ If in commercial societies diamonds are given as a sign of love by a hopeful bridegroom-to-be, in pre-commercial and noncommercial societies cows or gold are given as a price of his 'love' by the hopeful parents of the bride-to-be. Indeed, end values in general gained prominence in human life only with the increased wealth and leisure of commercial societies: witness the transformation of art from a largely didactic or religious value to a largely aesthetic value, and of the wilderness from something to be tamed and used to something to be valued for itself. ${ }^{85}$

\section{Conclusion}

I have argued that the critics of market societies misunderstand both markets and friendship by conceiving of them in radically dichotomous terms. Instrumentality, fungibility, impersonality, and so on come in varying degrees and characterize not only market, but also nonmarket, relationships, including friendship. Further, although market relations are primarily instrumental, they are not entirely so, because the individuals involved are not mere means to ends. It is this recognition that ultimately justifies the prohibition of force and fraud that is essential to a market relationship, and free markets are the most potent social force for promoting this recognition. Moreover, like all productive or creative activities, market activities play an important role in a meaningful life and, thus, are essentially structured by moral norms. For all these reasons, far from militating against friendship, market relations often give rise to friendship, and market societies are friendlier to civic and character friendship than any other developed form of society. 


\section{notes}

I started work on this article in 2002, during my year as a Visiting Scholar at Liberty Fund. I am grateful to Liberty Fund for the opportunity. An earlier and shorter version of this article appeared in Bernard Schumacher, ed. L'amitié (Paris: Presses Universitaires de France, 2005: 183-208), in the series Philosophie morale. As the publisher inadvertently omitted my acknowledgements from that article, I am taking this opportunity to thank Andrew J. Cohen, Adam Morton, Stephen Ellis, Bernard Schumacher, Richard Terdiman, and Lawrence White for their comments on the earlier version, Irfan Khawaja for his encouragement, and Richard Terdiman and Monte Cook for their painstaking help with the French translation. I am also grateful to the Joint Sessions of the Mind Association and the Aristotelian Society, University of Manchester (July 2005), Chapman University (April 2005), and the Association for Private Enterprise Education (April 2004) for the opportunity to present this article. And last but not least, I thank the referees of this journal for their incisive comments.

1. Many liberals have argued that political and civil rights play an important role in supporting civic and personal friendship, but to my knowledge no one has made a similar case for market freedoms or, more importantly, for the thesis that market relations and friendship share important features. On the defense of political and civil rights as supportive of friendship, see, in particular, Jeremy Waldron, 'When Justice Replaces Affection: The Need for Rights', Harvard Journal of Law and Public Policy 2 (1988): 635-47 and Allen E. Buchanan, 'Assessing the Communitarian Critique of Liberalism', Ethics 99 (1989): 852-82. In Neera Badhwar, 'The Circumstances of Justice: Liberalism, Community, and Friendship', Journal of Political Philosophy 1 (1993): 208-34, I argue against the communitarian charge that the primacy of negative rights and justice in liberal societies is inversely related to a sense of community by showing that the need for rights and justice is present in all communities, including the community called 'friendship', and that justice is a constitutive virtue of friendship.

2. Karl Marx, 'On the Jewish Question', in The Marx-Engels Reader, edited by R.C. Tucker (New York: Norton, 1972), pp. 40-1.

3. Erich Fromm, Man for Himself (London: Routledge and Kegan Paul, 1949), pp. 67-82.

4. Sybil Schwarzenbach, 'On Civic Friendship', Ethics 107 (1996): 97-128.

5. Elizabeth Anderson, Value in Ethics and Economics (Cambridge, MA: Harvard University Press, 1993), Ch. 7.

6. Margaret Radin, 'Market-Inalienability', Harvard Law Review 100 (1987): 1859-61.

7. Michael Sandel, 'The Procedural Republic and the Unencumbered Self', Political Theory 12 (1984): 93.

8. Charles Taylor, 'Atomism', Philosophy and the Human Sciences: Philosophical Papers, Vol. 2 (Cambridge: Cambridge University Press, 1985). See also Alasdair MacIntyre, After Virtue (Notre Dame, IN: Notre Dame University Press, 1981).

9. Richard Weaver, The Southern Tradition At Bay: A History of Postbellum Thought (New Rochelle, NY: Arlington House, 1968), pp. 52-9. Weaver's opposition to industrial or 'commodity' capitalism led him in his youth to join the American 
Socialist Party. Yet Weaver was more complex (or inconsistent, as the case may be) than my brief remarks in the text suggest: he defended the right to private property, praised libertarian writers such as Ludwig von Mises and Friedrich Hayek, and endorsed cultural pluralism. See Joseph Stromberg, 'Weaver of Liberty', URL: http://www.mises.org/story/623.

10. Erich Fromm, The Art of Loving (New York: Harper and Row, 1956), p. 8.

11. And even, sometimes, from imaginary harms done by various products. For example, as reported in R. Samuelson, 'Asbestos Fraud', URL: http://www.washingtonpost.com/wpdyn/ articles/A12624-2002Nov19.html, although asbestos use has gone down precipitously, asbestos law suits have risen dramatically, as trial lawyers take advantage of permissive tort laws to bring class lawsuits on behalf of individuals who have suffered no harm, and at the expense of businesses, their shareholders, and truly sick patients. Lawyers go hunting for 'victims' to represent with ads such as 'Find out if YOU have MILLION DOLLAR LUNGS.' Needless to say, none of this is meant to suggest that there are no justified asbestos law suits.

12. Radin, 'Market-Inalienability', and Anderson, Value in Ethics and Economics, Ch. 8.

13. Anderson, Value in Ethics and Economics, p. 172.

14. Radin, 'Market-Inalienability', pp. 1928-35.

15. Anderson, Value in Ethics and Economics, p. 154.

16. Ibid.

17. Ibid., p. 155.

18. Schwarzenbach, 'On Civic Friendship', p. 99.

19. Ibid., pp. 115-16.

20. Robert Putnam, Bowling Alone: The Collapse and Revival of American Community (New York: Simon and Schuster, 2000).

21. See, for example, Milton Friedman, Capitalism and Freedom (Chicago, IL: University of Chicago Press, 1962) and James Buchanan and Gordon Tullock, The Calculus of Consent: Logical Foundations of Constitutional Democracy (Indianapolis: Liberty Fund, 1999), pp. 267-9. To say that people are equal means simply that they cannot claim special privileges for themselves; under the rule of law, all have the same rights and obligations. But, of course, they may be unequal in their needs or talents or in what they have to offer for trade.

22. Anderson, Value in Ethics and Economics, pp. 170-82.

23. Ibid., pp. 170-5; Radin, 'Market-Inalienability', pp. 1928-35.

24. Anderson, Value in Ethics and Economics, p. 171.

25. See, for example, Steven N. Durlauf, 'Bowling Alone: A Review Essay', Journal of Economic Behavior and Organization 47(3) (2002): 259-73.

26. Putnam, Bowling Alone, pp. 2-3.

27. Ibid., p. 19.

28. Ibid., p. 351.

29. Ibid., pp. 319-22. Durlauf also discusses other problems with Putnam's conception of social capital, as well as with Putnam's causal analysis of the decline of social capital and its effects on individuals and society.

30. Giving USA 2006 (formerly the AAFRC Trust for Philanthropy), the yearbook of philanthropy published by the Giving USA Foundation, estimates that Americans 
gave a total of US $\$ 260.28$ billion for 2005 , which is a growth of 6.1 percent (2.7 percent adjusted for inflation) over 2004. See URL (accessed 31 July 2007): http://www.aafrc.org/press_releases/trustreleases/0606_PR.pdf.

Putnam agrees that private charity has grown in absolute numbers, but complains that it has shrunk greatly as a percentage of our wealth. See Putnam, Bowling Alone, pp. 122-3. In contrast, Giving USA claims that 'average charitable giving per household in 2005 is estimated to be 2.2 percent of average household disposable (after-tax) income, exactly at the 40-year average of 2.2 percent'.

Putnam also acknowledges the force of the argument made by many observers that, to the extent that social capital has been destroyed, it might be due to the 'crowding out' of private initiative by 'big government and the growth of the welfare state', but does not address the argument in any detail. For such an argument, see David Beito, “This Enormous Army”: The Mutual-Aid Tradition of American Fraternal Societies Before the Twentieth Century', The Voluntary City (Ann Arbor: University of Michigan Press, 2002), pp. 182-203. Tellingly, however, even Putnam agrees that Americans are more generous than the citizens of any other country, thus suggesting a link between a relatively individualistic, free-market culture and a relatively small welfare state, on the one hand, and generosity, on the other. For supporting research, see Herbert Gintis et al., 'Homo Reciprocans: A Research Initiative on the Origins, Dimensions and Policy Implications of Reciprocal Fairness', URL: http://www.umass.edu/preferen/rindex.htm.

31. Robert Wuthnow, Loose Connections: Joining Together in America's Fragmented Communities (Cambridge, MA: Harvard University Press, 1998). Even Putnam acknowledges that volunteering has gone up since 1975, that the internet has created new communities, and that self-help support groups and grassroots activity by evangelical conservatives have grown tremendously. He contends, however, that the overall evidence points to a decline of social capital since the 1960s. But this claim holds only because he counts political activities such as voting and working for political parties, or membership in labor unions, as social capital. But a decline in political partisan activity might be argued to represent a growth in wisdom about the nature of the two main parties, and a decline in union membership surely reflects, among other things, the dynamic nature of the American workplace and the fact that American workers are now better off than workers in almost any country.

32. Alexis de Tocqueville, Democracy in America, edited and translated by Harvey C. Mansfield and Delba Winthrop (Chicago, IL: University of Chicago Press, 2000).

33. Adam Ferguson, An Essay on the History of Civil Society, edited by F. OzSalzberger (Cambridge: Cambridge University Press, 1995 [1767]), VI.I, p. 231.

34. Ferdinand Tönnies, Community and Society, edited and translated by Charles Loomis (New York: Harper and Row, 1963 [1887]).

35. Anderson, Value in Ethics and Economics, pp. 144-5.

36. Ibid., p. 144.

37. The intrinsic values they want protected range from motherhood and sexuality (Anderson and Radin) and civic friendship (Schwarzenbach) to labor and housing (Radin). Anderson also objects to governments treating public health and safety and the environment as mere commodities. See Anderson, Value in Ethics and Economics, Ch. 9.

38. Ibid., p. 143. 
39. Ibid., p. 144.

40. Ibid., pp. 145-6.

41. Schwarzenbach, 'On Civic Friendship', p. 105.

42. Ibid., pp. 115-16.

43. Anderson, Value in Ethics and Economics, p. 151.

44. Ibid., p. 144.

45. Ibid., pp. 151-2.

46. Schwarzenbach, 'On Civic Friendship', p. 103.

47. Thanks to a referee of this journal for prompting me to clarify this point.

48. Aristotle, Nicomachean Ethics, translated by Terence Irwin (Indianapolis: Hackett, 1985), Bk. VIII.

49. Ibid. There are, however, two differences between Aristotle's conception of utility friendships and mine. Aristotle's utility friendships are formed for the sake of utility, whereas the kind I am discussing are outgrowths of relationships based on utility, but are not for the sake of utility: people do not need to be friends to trade with each other. Further, unlike Aristotle, I regard utility friendships as involving pleasure in each other's company and not only in each other's utility, even though utility is a necessary condition for the friendship.

50. I owe this point to Adam Morton.

51. Adam Smith, The Theory of Moral Sentiments (London: A. Millar, 1790), VI.II.18. URL: http://www.econlib.org/library/Smith/smMS0.html. On my reading of Smith, commercial society encourages a better form of necessitudo, that between mutually dependent equals, because it spreads equality. This differs from Allan Silver's reading of Smith, on which commercial society replaces necessitudo with a superior form of friendship. See Allan Silver, 'Friendship in Commercial Society:

Eighteenth-Century Social Theory and Modern Sociology', American Journal of Sociology 95(6) (1990): 1474-504. This is a puzzling reading, since Smith makes it clear that colleagues and 'partners in trade' form attachments because of their frequent intercourse and proximity. My reading of this passage also differs from that in Lisa Hill and Peter McCarthy, 'Hume, Smith and Ferguson: Friendship in Commercial Society', in The Challenge to Friendship in Modernity, edited by Preston King and Heather Devere (London: Frank Cass, 2000), pp. 33-49. They argue that Smith reduces necessitudo to a business strategy adopted entirely 'for the sake of commerce' (38), since 'amity between people in the workplace is desirable and conducive to business' (35).

52. This is a point that cannot be accommodated by those who identify business relationships with business friendships. See Douglas J. Den Uyl and Douglas B. Rasmussen, 'Aristotelianism, Commerce, and the Liberal Order', in Aristotle and Modern Politics, edited by A. Tessitore (Notre Dame, IN: University of Notre Dame Press, 2002), pp. 296, 301, who argue that a mutually recognized well-wishing, even if entirely instrumental, is sufficient for friendship, and that even transient business relationships involve such well-wishing. But wishing someone well insofar as he is useful is compatible with disliking him as a person, and dislike is incompatible with friendship. Compare J.M. Cooper, 'Aristotle on the Forms of Friendship', Review of Metaphysics 30 (1997): 638-9, who, rightly, distinguishes business relationships as such from business friendships by making genuine mutual liking and goodwill within 'the general context of profitability' essential to the latter. 
53. The mechanisms of trust created by the merchants are described in Barak Richman, 'How Community Institutions Create Economic Advantage: Jewish Diamond Merchants in New York', Law and Social Inquiry 31 (2006): 383-420.

54. Anderson also argues that the market is oriented to 'exit' rather than 'voice'. See Anderson, Value in Ethics and Economics, p. 146. Assuming that we can make a clear distinction between the two, I see it as a virtue of markets that we can shape them largely by choosing what we buy and where we shop (exit) - an ongoing casting of 'votes' with our money that allows even 'economic minorities', such as diabetics or vegans, to satisfy their preferences. Most of us would not want to do any more market surveys (voice), much less lobby congressmen or demonstrate on the streets (voice), to shape the market. At the same time, in some sorts of commercial establishments, such as restaurants, we do shape the offerings to some extent by conveying our preferences to our servers (voice). Thanks to Larry White for this example.

55. Schwarzenbach, 'On Civic Friendship', p. 102.

56. Ibid., p. 103.

57. Even in such a friendship, however, the friends can be, indeed, must be, fair, generous, loyal, trustworthy, and so on toward or with each other, since without these attitudes their friendship cannot count as an end in itself.

58. Schwarzenbach, 'On Civic Friendship', pp. 102, 103.

59. Ibid., p. 103 (emphasis added).

60. Fromm, Man for Himself, p. 84.

61. Ibid., p. 86.

62. Virginia Postrel, The Future and its Enemies (New York: Touchstone, 1998), p. 34.

63. Ludwig von Mises, Human Action (Irvington: Foundation for Economic Education, 1996).

64. Fromm, The Art of Loving, p. 8.

65. Adrienne Rich, 'Women and Honor: Some Notes on Lying' from On Lies, Secrets, and Silence: Selected Prose, 1966-1978, reprinted in The Experience of Philosophy, edited by Raymond Martin and Daniel Kolak (Belmont, CA: Wadsworth, 1990), pp. $475-8$.

66. Ibid., p. 475.

67. Aristotle, Nicomachean Ethics, 1165b 6-13.

68. Thanks to a referee of this journal for raising this objection.

69. See the humorous article by John Newlin, 'A Friend in the Diamond Business?' The Wave Magazine, URL:

http://www.thewavemag.com/pagegen.php?pagename=article\&articleid=22245.

Despite the humor, Newlin does seem to think that the company was lying in claiming that he had a friend there.

70. Rich, On Lies, Secrets, and Silence, p. 474.

71. See Thomas Donaldson and Al Gini, Case Studies in Business Ethics (New Jersey: Prentice Hall, 1984), pp. 33-4.

72. But calling manipulation and so on in commerce wrong even when it does not amount to fraud does not imply that it should be made illegal, any more than calling manipulation or deception in personal relationships wrong implies that it should be made illegal.

73. See C.S. Lewis, 'Friendship', in The Four Loves (New York: Harvest Books, 1971), pp. 57-90. 
74. Anderson, Value in Ethics and Economics, p. 151.

75. For example, Weaver, The Southern Tradition at Bay, pp. 49-50, 52.

76. A democracy without a free-market economy is not enough for equality, as shown by the fact that democracies with highly regulated economies, such as India (especially before 1991) continue to be radically unequal and radically hierarchical.

77. David Hume, Essays, Moral, Political, and Literary, edited by Eugene F. Miller (Indianapolis: Liberty Fund, 1987), II.1.4, II.II.9. Available online at URL: http://www.econlib.org/library/LFBooks/Hume/hmMPL1.html. Smith, Theory of Moral Sentiments, VI.II.21 and Adam Smith, An Inquiry into the Nature and Causes of the Wealth of Nations, edited by Edwin Cannan (London: Methuen, 1904), III.IV.4. Available online at URL: http://www.econlib.org/library/Smith/smWN11.html.

78. Hume, Essays, Moral, Political, and Literary, II.II.16; Smith, Wealth of Nations, III.IV.4-7.

79. Smith, Theory of Moral Sentiments, VI.II.15-16.

80. Silver, 'Friendship in Commercial Society', pp. 1482-4.

81. Hume, Essays, Moral, Political, and Literary, II.II.3-5.

82. Norbert Elias, The Court Society (New York: Pantheon, 1983 [1969]), p. 111, cited in Silver, 'Friendship in Commercial Societies', p. 1500. See also Choderlos de Laclos' Dangerous Liaisons for vivid descriptions of pretend friendships and cruel prestige struggles.

83. Smith, Theory of Moral Sentiments, VI.II.21 and Smith, Wealth of Nations, III.IV.4-7. Silver goes so far as to say that Smith regards commercial society as creating the friendship of virtue. However, Smith can hardly have been unaware that there were always friendships of virtue. What commercial society does is provide greater opportunities for the friendship of virtue by widening people's circles of friends. Hill and McCarthy, 'Hume, Smith and Ferguson' make the opposite mistake of completely omitting the friendship of virtue from their discussion.

84. See E. Hatfield and R. Rapson, Love, Sex, and Intimacy: Their Psychology, Biology, and History (Boston, MA: Allyn and Bacon, 1997).

85. See Tyler Cowen, In Praise of Commercial Culture (Cambridge, MA: Harvard University Press, 1998) on how markets promote artistic diversity and make art cheaply available to the public, and Terry L. Anderson and Donald R. Leal, Free Market Environmentalism, revised edn (New York: Palgrave, 2001), pp. 43-6, on the change in attitudes toward nature associated with rising wealth from 1857 to 1872. Contrary to popular misconceptions, the first conservation efforts were made by private individuals and commercial interests that, among other things, established the first national parks. Yellowstone National Park, for example, was established by the Northern Pacific Railroad in 1872. See Anderson and Leal, Free Market Environmentalism, pp. 45-6. 